waiting time for transplantation-now averaging two years ${ }^{15}$ are self evident.

This series shows the value of HLA matching of donor and recipient for two, three, or four antigens, which was particularly important for the long-term survival of the transplants. As $77 \%$ of transplant failures after 12 months were due to rejection it appears that close HLA matching of donor and recipient confers considerable benefit in decreasing kidney loss due to late rejection. The importance of the first transplant, which had significantly the lowest primary failure rate as compared with second and third transplants, was also evident, despite the second and third transplants being performed only in the absence of recipient cytotoxic and haemagglutinating antibodies to donor tissue.

Analysis of the causes of the loss of transplants (table II) shows that rejection was responsible in $52^{\circ} \%$ of cases, that the death of the patient with a functioning transplant was responsible in $30 \%$, that renal vascular thrombosis was responsible in $12 \%$, and that miscellaneous causes, including urinary leak and kidney necrosis due to causes other than rejection, were responsible in $6 \%$. Transplant loss due to renal vascular thrombosis and miscellaneous causes resulted mainly from using cadaver kidneys unsuitable for transplantation. These kidneys, which originated from non-ventilated donors or had vascular anomalies or prolonged ischaemic times, constituted half of the primary failures, and elimination of these high-risk kidneys has been shown to reduce the primary failure rate from $21 \%$ overall to $11^{\%} \%$, which was due mainly to rejection. The incidence of rejection may be reduced by close HLA matching of donor and recipient. When the donor and recipient had two or more antigens in common the three-year kidney survival rate was $46 \%$, as opposed to $9.5 \%$ for poorer matches. Altogether $21 \%$ of the patients died with functioning transplants and $40 \%$ of the deaths appeared to be due to infections with bacteria sensitive to conventional antibiotics. Intensive antibiotic treatment sometimes failed in the immunosuppressed patient owing to the emergence of resistant bacteria, opportunistic organisms, and infection with several different organisms. The importance of using only low-risk kidneys with the best possible HLA matching and scrupulous patient care is shown by the finding that if the patient survives one year with a functioning transplant there is a $77^{\circ}$ chance of surviving to at least three years with satisfactory renal function.

Clearly for the results of cadaver kidney transplantation to be improved more kidneys are required from well maintained donors to enable the strict selection of only kidneys that are suitable for transplantation to be made. Then the three-year functioning kidney transplant survival rate should improve to more than $50 \%$ instead of the $31 \%$ reported at present. For this to be achieved changes will be required in both medical and public attitudes that prevail in Britain to cadaver kidney transplantation.

We acknowledge the generous help of Professor D B Brewer, who performed the histological examination of the kidney transplants.

\section{References}

${ }^{1}$ Murray, J E, Barnes, B A, and Atkinson, J L, Transplantation, 1971, 11, 328.

2 Barnes, B A, et al, Fournal of the American Medical Association, 1973, 226, 1197.

${ }^{3}$ Robinson, B H B, et al, European Dialysis and Transplant Association, 1972, 9, 109.

${ }^{4}$ Hall, C L, et al, Lancet, 1974, 1, 532.

${ }^{5}$ Hall, C L, et al, British Medical fournal, 1975, 3, 667.

${ }^{6}$ Edwards, J H, Tissue Antigens, 1974, 4, 580.

7 Barnes, A D, et al. In preparation.

8 Sheil, A G R, et al, Lancet, 1971, 1, 359.

9 Bell, P F R, et al, British Medical fournal, 1972, 4, 408.

10 Tomlinson, S A, et al, British Medical fournal, 1974, 4, 553.

11 Hulme, B, et al, British Medical fournal, 1972, 4, 139.

12 Festenstein, $\mathrm{H}$, et al, Lancet, 1971, 2, 225.

${ }^{13}$ Nelson, S D, and Tovey, G H, British Medical for'rnal, 1974, 1, 622

${ }_{14}$ British Medical fournal, 1974, 3, 703.

15 Farrow, S C, Fisher, D J, and Johnson, D B, British Medical fournal, $1972,3,686$.

\title{
Streptokinase in central retinal vein occlusion: a controlled clinical trial
}

\author{
EVA M KOHNER, J E PETTIT, A M HAMILTON, C J BULPITT, C T DOLLERY
}

of clinical and laboratory values and similar in their initial visual acuity. At follow-up ("final" vision) the visual acuity in the treated group was significantly better than in the untreated group. Only one treated patient developed thrombotic glaucoma compared with four controls. Streptokinase may, however, have been responsible for vitreous haemorrhage (and permanent loss of vision) in three patients and hence probably has only a limited role in the treatment of central retinal vein occlusion.

Hammersmith Hospital, London W12 0HS

EVA M KOHNER, MD, MRCP, lecturer in medicine C J BULPITT, MSC, MRCP, honorary consultant in medicine

C T DOLLERY, MB, FRCP, consultant physician

Royal Free Hospital, London NW3

J E PETTIT, MD, MRCPATH, consultant haematologist

Retinal Diagnostic Unit, Moorfields Eye Hospital, London EC1

A M HAMILTON, FRCs, resident surgeon

\section{Introduction}

Several reports ${ }^{1-4}$ have indicated that anticoagulants and fibrinolytic agents may be of benefit in retinal vein occlusion. These studies, however, were uncontrolled and patients with both central and branch vein occlusion were included. Because of the variable history of central retinal vein occlusion only randomised, controlled studies will show the efficacy of any treatment. Such a study is reported here. 


\section{Patients and methods}

Patients presenting at the Hammersmith Hospital or Moorfields Eye Hospital within seven days after their first visual symptoms of central retinal vein occlusion were eligible for inclusion in the study. Criteria for their exclusion included contraindications to fibrinolytic agents or anticoagulants and the presence of other eye diseasefor example, diabetic retinopathy. All the patients were admitted to hospital for medical evaluation and treatment when required. The experimental nature of the treatment was explained to the patients after ophthalmological and medical examination and their informed consent to inclusion in the study obtained. They were then allocated at random to a "treatment" or "control" group. Control patients were kept in hospital for not less than three days and received no specific treatment.

Between 1 April 1971 and 31 March 1974, 41 patients were seen who were suitable for fibrinolytic treatment. One withdrew after being allocated to the treatment group but before treatment began and was excluded from the study. Of the remaining 40 patients 20 were in the treated group and 20 in the control group. Our aim was to follow up the patients for one year after their first visit. Two, however, emigrated after six months, and for them the six-month visual acuity was taken as the "final" (one-year) reading. Details of the patients are given in tables I-III.

Contraindications to streptokinase include: (1) known haematological disorders associated with an increased risk of haemorrhage; (2) active peptic ulcer; (3) renal failure with a plasma urea of $16.6 \mathrm{mmol} / \mathrm{l}$ $(100 \mathrm{mg} / 100 \mathrm{ml})$ or higher; (4) pregnancy; (5) a history of cerebrovascular accident; (6) recent surgery (within seven days); and (7) a diastolic blood pressure of over $110 \mathrm{mg} \mathrm{Hg}$, though patients could enter the trial if the blood pressure was controlled and the diastolic pressure had been kept below this level for at least 24 hours.

Treatment schedule-Patients were given $10 \mathrm{mg}$ chlorpheniramine (Piriton) intravenously before a loading dose of streptokinase 600000 units in $300 \mathrm{ml}$ dextrose saline given intravenously over 30 minutes. This was followed by maintenance treatment with streptokinase 100000 units in $100 \mathrm{ml}$ physiological saline hourly for 72 hours. At the end of this thrombolytic treatment the patients were given a loading dose of warfarin (30-40 mg) and an intravenous infusion of heparin 30000 units $/ 24$ hours for 48 hours. During six months of oral anticoagulation the warfarin dosage was adjusted to maintain Thrombotest values at between $8 \%$ and $12 \%$.

Haematological studies-Tests to monitor the effect of streptokinase were performed on 14 patients. Blood samples were taken before treatment and on each day of treatment. The thrombin time and euglobulin clot lysis time were measured by standard techniques. Fibrinogen was measured as thrombin clottable protein by a modification of Ratnoff and Menzie's ${ }^{6}$ method. Plasma plasminogen concentration was estimated by the method of Alkjaersig et al, ${ }^{7}$ and the split products of fibrinogen and fibrin in serum were measured immunologically using antifibrinogen serum and a modified haemagglutination technique. ${ }^{8}$

Ophthalmological assessments-The eyes were examined on admission, before discharge from hospital, and at about six weeks and three, six, and 12 months after the initial symptoms. Visual acuity was determined with the Snellen test type. Intraocular pressure was measured and the anterior segment examined. Retinal examination was supplemented by colour and fluorescence photography when possible.

Statistical analysis-For statistical analysis visual acuity was converted to numerical grades. ${ }^{9}$ With this method $6 / 6=1,6 / 9=2$, etc until no perception of light $=12$. The treated and control groups were compared by using Student's $t$ test. Fisher's exact test ${ }^{10}$ was used to compare complications in the two groups.

\section{Results}

\section{COMPARABILITY OF PATIENTS}

Although the two groups of patients were comparable in most respects (tables I and II), there were some differences. There were more treated women than men, and the converse was true in the control group. The ESR was significantly higher in the treated group, and the serum urate was significantly higher in the controls. While this latter finding could have been related to the sex difference, these differences occurred by chance. There was no reason to believe that they would invalidate the results.

The initial visual acuities were similar and there was no significant difference between men and women (table III). Chronic simple
TABLE I-Sex distribution of patients in treated and control groups and mean clinical and laboratory values $( \pm S E)$

\begin{tabular}{|c|c|c|c|}
\hline & & $\begin{array}{l}\text { Treated group } \\
\quad(\mathrm{n}=20)\end{array}$ & $\begin{array}{l}\text { Controls } \\
(\mathrm{n}=20)\end{array}$ \\
\hline 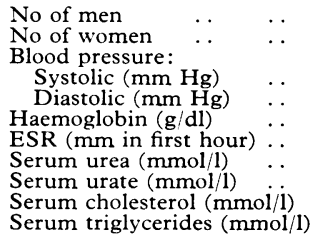 & $\begin{array}{l}\cdots \\
\cdots \\
\cdots \\
\cdots \\
\cdots \\
\cdots \\
\cdots\end{array}$ & $\begin{array}{c}7 \\
13 \\
169 \cdot 8 \pm 9 \cdot 4 \\
95 \cdot 9 \pm 5 \cdot 1 \\
13 \cdot 3 \pm 0 \cdot 3 \\
20 \cdot 45 \pm 1 \cdot 5^{*} \\
5 \cdot 53 \pm 0 \cdot 45 \\
0 \cdot 30 \pm 0 \cdot 022^{*} \\
5 \cdot 58 \pm 0 \cdot 262 \\
1 \cdot 376 \pm 0 \cdot 16\end{array}$ & $\begin{array}{c}14 \\
6 \\
167 \cdot 0 \pm 6 \cdot 4 \\
97 \cdot 7 \pm 3 \cdot 2 \\
13 \cdot 9 \pm 0 \cdot 4 \\
13 \cdot 09 \pm 0 \cdot 9^{*} \\
5 \cdot 83 \pm 0 \cdot 32 \\
0 \cdot 36 \pm 0 \cdot 014^{*} \\
6 \cdot 105 \pm 0 \cdot 35 \\
1 \cdot 758 \pm 0 \cdot 26\end{array}$ \\
\hline
\end{tabular}

${ }^{*} \mathrm{P}<0.05$.

Conversion: SI to traditional units-Urea: $1 \mathrm{mmol} / 1 \approx 6 \mathrm{mg} / 100 \mathrm{ml}$. Urate: $1 \mathrm{mmol} / 1$ $\approx 17 \mathrm{mg} / 100 \mathrm{ml}$. Cholesterol: $1 \mathrm{mmol} / 1 \approx 38.6 \mathrm{mg} / 100 \mathrm{ml}$. Triglycerides: $1 \mathrm{mmol} / 1$ $\approx 88.5 \mathrm{mg} / 100 \mathrm{ml}$

TABLE II-Age distribution of patients in the two groups

\begin{tabular}{|c|c|c|c|c|c|c|c|}
\hline & \multirow{2}{*}{$\begin{array}{l}\text { Mean age } \\
\text { in years } \\
\text { (range) }\end{array}$} & \multicolumn{6}{|c|}{ No in each age group (years) } \\
\hline & & $<40$ & $40-$ & $50-$ & $60-$ & $70-79$ & Total \\
\hline $\begin{array}{l}\text { Treated group } \\
\text { Controls } \ldots\end{array}$ & $\begin{array}{l}58 \cdot 3(21-78) \\
54 \cdot 8(18-73)\end{array}$ & $\begin{array}{l}3 \\
5\end{array}$ & $\begin{array}{l}4 \\
1\end{array}$ & $\begin{array}{l}1 \\
3\end{array}$ & $\begin{array}{r}8 \\
10\end{array}$ & $\begin{array}{l}4 \\
1\end{array}$ & $\begin{array}{l}20 \\
20\end{array}$ \\
\hline
\end{tabular}

TABLE III-Mean visual acuity grades (see text) in the two groups initially and at follow-up (final vision)

\begin{tabular}{|c|c|c|c|c|c|c|c|}
\hline & \multicolumn{3}{|c|}{ Treated group } & \multicolumn{3}{|c|}{ Controls } \\
\hline & & Men & Women & Total & Men & Women & Total \\
\hline $\begin{array}{l}\text { Initial vision } \\
\text { Final vision } \\
\text { Change in vision }\end{array}$ & $\begin{array}{l}\ldots \\
\cdots\end{array}$ & $\begin{array}{r}7 \cdot 1 \\
6 \cdot 3 \\
+1 \cdot 1\end{array}$ & $\begin{array}{r}6 \cdot 1 \\
5 \cdot 3 \\
+1 \cdot 4\end{array}$ & $\begin{array}{c}6.9 \\
5.6 \\
+1.3 *\end{array}$ & $\begin{array}{r}5 \cdot 0 \\
6 \cdot 2 \\
-1 \cdot 2 \\
\end{array}$ & $\begin{array}{r}5.8 \\
7.6 \\
-1.8\end{array}$ & $\begin{array}{r}5 \cdot 6 \\
7.1 \\
-1.5 *\end{array}$ \\
\hline
\end{tabular}

$* \mathrm{P}<0.03$

glaucoma was present in the fellow eye-and therefore thought to be a predisposing cause-in three control and two treated patients.

\section{LABORATORY RESULTS}

Streptokinase treatment was associated with a prolongation of the thrombin time in all monitored patients (table IV), the largest increase occurring in the first 24 hours. Increased levels of circulating plasminogen activator were shown by shortened euglobulin clot lysis times, and the plasma plasminogen levels fell to about $50 \%$ of normal during the first day of treatment and remained similarly reduced throughout. Maximum levels of split products of fibrinogen/fibrin were found in the serum during the first day of treatment, and raised levels continued to be present during the second and third days.

\section{VISUAL ACUITY}

The initial visual acuities were similar in the two groups (table III), the median values being $6 / 36$ in the control group and $6 / 60$ in the treated group. When the change in visual acuity between the initial

TABLE IV-Results of laboratory tests in treated patients

\begin{tabular}{|c|c|c|c|c|c|}
\hline & $\begin{array}{c}\text { Thrombin } \\
\text { time }\end{array}$ & $\begin{array}{l}\text { Euglobulin } \\
\text { clot } \\
\text { lysis time } \\
\text { (min) }\end{array}$ & $\begin{array}{c}\text { Plasma } \\
\text { plasminogen } \\
\text { (casein } \\
\text { units } / \mathrm{ml} \text { ) }\end{array}$ & $\begin{array}{c}\text { Plasma } \\
\text { fibrinogen } \\
(\mathrm{g} / \mathrm{l})\end{array}$ & $\begin{array}{l}\text { Serum fibrin/ } \\
\text { fibrinogen } \\
\text { split } \\
\text { products } \\
\text { (mg/l) }\end{array}$ \\
\hline $\begin{array}{l}\text { Norman } \\
\text { values }\end{array}$ & $9-11$ & $90-240$ & $1 \cdot 5-4 \cdot 0$ & $1 \cdot 5-4 \cdot 0$ & $\begin{array}{l}\text { Not } \\
\text { detectable }\end{array}$ \\
\hline $\begin{array}{l}\text { Mean } \\
\text { Range }\end{array}$ & $\begin{array}{l}10 \cdot 75 \\
9 \cdot 7-11 \cdot 6\end{array}$ & $>90^{\text {Befor }}$ & $\begin{array}{l}\text { atment } \\
3 \cdot 15 \\
1 \cdot 7-4 \cdot 2\end{array}$ & $\begin{array}{l}2 \cdot 86 \\
2 \cdot 0-3 \cdot 48\end{array}$ & $\begin{array}{l}\text { Not } \\
\text { detected }\end{array}$ \\
\hline $\begin{array}{l}\text { Mean } \\
\text { Range }\end{array}$ & $\begin{array}{l}41 \cdot 5 \\
15-64\end{array}$ & $\begin{array}{l}22 \\
10-50\end{array}$ & $\begin{array}{l}0 \cdot 16 \\
0-0 \cdot 25\end{array}$ & $\begin{array}{l}1 \cdot 13 \\
0 \cdot 65-1 \cdot 78\end{array}$ & \begin{tabular}{|l}
467 \\
$64-1024$
\end{tabular} \\
\hline $\begin{array}{l}\text { Mean } \\
\text { Range }\end{array}$ & $\begin{array}{l}22 \cdot 2 \\
13-30 \cdot 5\end{array}$ & $\begin{array}{l}17 \cdot 5 \\
10-22\end{array}$ & $\begin{array}{l}0 \cdot 17 \\
0-0 \cdot 45\end{array}$ & $\begin{array}{l}1.26 \\
0.58-1.68\end{array}$ & $\begin{array}{l}327 \\
16-512\end{array}$ \\
\hline $\begin{array}{l}\text { Mean } \\
\text { Range }\end{array}$ & $\begin{array}{l}21 \cdot 6 \\
12-26\end{array}$ & $\begin{array}{l}18 \cdot 0 \\
10-22\end{array}$ & $\begin{array}{c}0 \cdot 17 \\
0-0 \cdot 38\end{array}$ & $\begin{array}{l}1 \cdot 24 \\
0 \cdot 70-1 \cdot 81\end{array}$ & $\begin{array}{l}73 \cdot 2 \\
8-128\end{array}$ \\
\hline
\end{tabular}


and final vision was compared in the two groups the treated group was found to have fared significantly better $(P<0.03)$ (table III), more patients having improved and fewer deteriorated than in the untreated group: altogether five of the treated patients compared with 12 of the controls had a deterioration in vision (figs 1 and 2). Furthermore, only one treated patient with an initial vision of $6 / 36$ or better deteriorated to blindness $(6 / 60$ or worse), whereas seven of the controls lost vision to this degree. The improvement in vision occurred in both sexes and was not due to an excess of women in the treated group (table III).

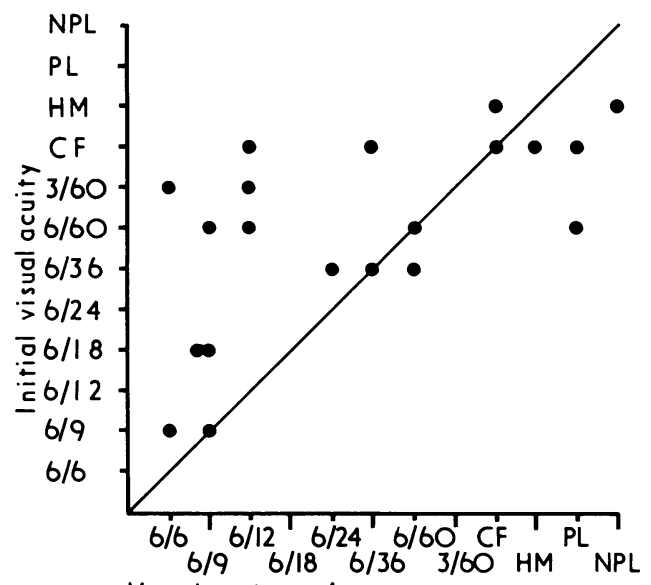

Visual acuity of 1 year

FIG 1-Comparison between initial and final visual acuity in patients receiving streptokinase. Each dot represents one eye. $\mathrm{CF}=$ Count fingers. $\mathrm{HM}=$ Hand movement. $\mathrm{PL}=$ Perception of light. $\mathrm{NPL}=$ No perception of light.

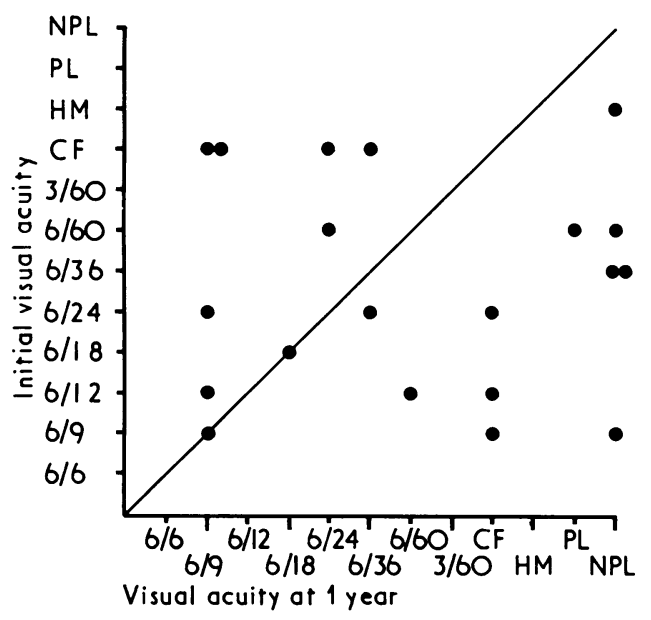

FIG 2-Comparison between initial and final visual acuity of control eyes. Key to symbols as in fig 1 .

\section{COMPLICATIONS}

Visual-Complications were common in both groups (table V). Vitreous haemorrhage was the most common and occurred in four control and three treated patients. But while it was a complication of developing new vessels in the controls and a late manifestation of the disease (3-12 months), in the treated patients it occurred within the first three days-that is, while they were receiving streptokinase. Thus

TABLE v-Eye complications occurring in treated and control groups

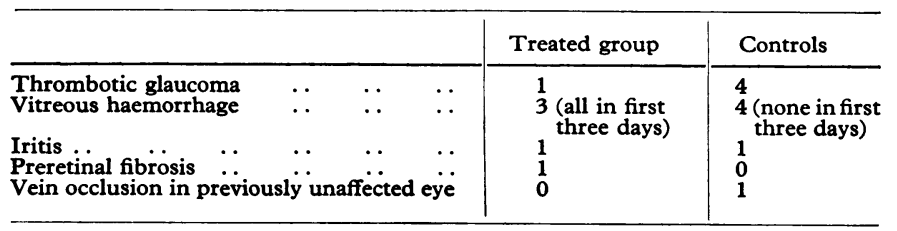

it was probably due to the treatment. All eyes with vitreous haemorrhage became and remained blind.

Thrombotic glaucoma occurred in four of the controls $(20 \%)$ but in only one treated patient $(5 \%)$. This difference was not significant. One patient in each group had transient iritis. One control patient developed vein occlusion in his previously unaffected eye.

Complications due to streptokinase-All patients receiving streptokinase suffered minor discomfort and haematomas at the site of venipunctures. One developed severe bruising over pressure sites. Two patients had arthralgia and rashes within 10 days of streptokinase. Both these patients improved before discharge from hospital.

\section{Discussion}

In this study streptokinase was shown to have a small but definitely beneficial effect on the visual outcome of central retinal vein occlusion. It also seemed to give some protection from the painful complication of thrombotic glaucoma. Disappointingly, however, the treatment was not more effective, 11 of the 20 treated eyes ending up with a visual acuity of $6 / 24$ or worse, and three becoming blind, probably as a result of treatment.

If thrombosis was the main cause of the clinical manifestation of the lesion a more favourable outcome might have been expected, since the thrombolytic effect of the treatment was clearly shown by the laboratory tests performed (table IV). There are two possibilities to explain the lack of success. Firstly, the occlusion may have been present for longer than the clinical symptoms suggested. This possibility is particularly likely in elderly patients, who often are not aware of venous occlusion until they happen to close their good eye. It is noteworthy that two of the earliest presentations were in patients who were already blind in one eye at the time of the vein occlusion, and the one treated achieved an excellent result. The other possibility is that thrombosis is only partial or a final event superimposed on an underlying abnormality. The main cause of obstruction could be pressure from the neighbouring artery or obstruction due to endothelial cell proliferation, as found by Klien and Olwin ${ }^{11}$ in a necropsy study. The final outcome would then depend on the site of occlusion and the availability of other routes for venous drainage and the development of collaterals. That compression may be important was indicated by Ancel, ${ }^{12}$ who obtained good results with some improvement in vision in seven patients after decompression operations on the optic nerve sheath and scleral ring.

The small differences between our two groups of patients are unlikely to have affected the results. In a recent study of the history of the lesion in 75 untreated patients there was no evidence that the visual outcome differed with sex. ${ }^{13}$ One possible criticism is that the control patients were not confined to bed and had no control saline infusion and were thus treated differently from those receiving streptokinase. Because increased amounts of blood plasminogen activator may be detected after even moderate exercise such as walking ${ }^{14-15}$ we decided not to confine the control patients to bed for the first five days of their admission.

Our findings suggest that streptokinase has a small but positive role in the treatment of central retinal vein occlusion. It is probably most effective in conditions in which thrombosis is of primary importance, such as venous occlusion occurring during oral contraceptive treatment. Because of the complications, particularly vitreous haemorrhage, it should otherwise probably be used only in those who are already blind in one eye.

This study was supported by a grant from the Wellcome Trust. We gratefully acknowledge the work of all those who shared in the management of the patients, particularly the house physicians of Professor Dollery, members of the haematology department of Hammersmith Hospital, and the casualty officers at Moorfields Eye Hospital. We thank Mr R K Blach and other consultants at Moorfields Eye Hospital for allowing us to study patients under their care. The illustrations were prepared by Ray Humphrey. 


\section{References}

1 Vannas, S, and Orma, H, Archives of Ophthalmology, 1957, 58, 812.

${ }^{2}$ Hiemeyer, V, Deutsche medizinische Wochenschrift, 1967, 92, 955.

3 Ottolander, G J H, and Craandijk, A, Thrombosis et Diathesis Haemorrhagica, 1968, 20, 415 .

${ }^{4}$ Rossman, H, Postgraduate Medical fournal, 1973, 49, suppl (August), p 105.

5 Dacie, J V, and Lewis, S M, Practical Haematology. London, Churchill, 1968.

${ }^{6}$ Ratnoff, O D, and Menzie, C, Fournal of Laboratory and Clinical Medicine, $1951,37,316$.
' Alkjaersig, N, Fletcher, A P, and Sherry, S, fournal of Clinical Investigation, 1959, 38, 1086 .

${ }^{8}$ Merskey, C, Kleiner, G J, and Johnson, A J, Blood, 1966, 28, 1.

${ }^{9}$ Joplin, G F, et al, Diabetologia, 1967, 3, 406.

10 Snedecor, G W, and Cochran, W G, Statistical Methods, 4th edn, p 236. Iowa State University Press, 1969.

${ }^{11}$ Klien, B A, and Olwin, J H, Archives of Ophthalmology, 1956, 56, 207.

12 Ancel, B, personal communication.

13 Laatikeinen, L, and Kohner, E M. In press.

${ }^{14}$ Cash, J D, British Medical fournal, 1969, 2, 502.

15 Sawyer, W D, et al, fournal of Clinical Investigation, 1960, 39, 426.

16 Ogston, D, and Fullerton, H, Lancet, 1961, 2, 730.

\title{
Islet-cell, thyroid, and gastric autoantibodies in diabetic identical twins
}

\author{
R LENDRUM， P G NELSON, D A PYKE, G WALKER, D R GAMBLE
}

British Medical fournal, 1976, 1, 553-555

\section{Summary}

Sera from 54 pairs of identical twins, 29 discordant and 25 concordant for insulin-dependent diabetes, and 11 pairs of concordant non-insulin dependent identical twins were examined for pancreatic islet-cell antibodies (ICAs). ICAs were found in 10 of the 29 diabetic discordant and eight of the 50 concordant twins (difference not significant $P>0 \cdot 05$ ). Six out of nine twins tested within one year of onset of diabetes were positive, whereas nine out of 29 tested after one to 10 years and three out of 41 tested after 10 years were positive. Only one of the 22 non-insulin-dependent twins had ICAs. Repeat ICA testing in five pairs of insulin-dependent twins and in the siblings of one pair showed that ICAs may be present in people with normal glucose tolerance; may precede clinical diabetes by several years; and may decline in titre or disappear with increasing duration of disease.

Thyroid or gastric autoantibodies, or both, were found in 36 out of 108 insulin-dependent twins and three out of 22 non-insulin dependent twins (difference not significant $P>0.05)$. Only four twins had both ICAs and thyrogastric antibodies. There were no significant associations between autoantibodies and HLA histocompatibility types.

As ICAs are more common in the diabetic than the non-diabetic twins of the discordant pairs they must be associated with juvenile onset diabetes. ICAs may appear some years before the onset of diabetes, but their prevalence declines with increasing duration of diabetes. The factors determining the production of ICA differ from those for thyroid and gastric autoantibodies.

Department of Gastroenterology, St Mary's Hospital, London W2 $R$ LENDRUM, MRCP, research fellow

G WALKER, FRCP, consultant physician

Diabetic Department, King's College Hospital, London SE5 9RS P G NELSON, MRCP, research fellow

D A PYKE, FRCP, consultant physician

Public Health Laboratory, West Park Hospital, Epsom, Surrey D R GAMBLE, FRCPATH, director

\section{Introduction}

Humoral autoimmunity directed against pancreatic islets ${ }^{1}{ }^{2}$ occurs in about half of newly diagnosed diabetic children. ${ }^{3}$ The relative importance of genetic and environmental factors in the production of these antibodies is not known. In a recent study of insulin-dependent diabetic identical twins ${ }^{4}$ one-half were concordant (both twins diabetic) and the remainder discordant (only one twin affected). While it is now thought that there is genetic susceptibility to diabetes in both groups, since both discordant and concordant pairs show certain HLA associations, ${ }^{5}$ environmental factors must also be implicated in the aetiology of diabetes in the discordant pairs.

In an attempt to determine the importance of autoimmunity in the aetiology of insulin-dependent diabetes we tested identical twins for the presence of islet-cell antibodies (ICAs). We also tested the twins for thyrogastric autoantibodies.

\section{Patients and methods}

The identical twins were part of a larger series described elsewhere. ${ }^{4}$ Stored serum samples were examined from: 29 twin pairs discordant for insulin-dependent diabetes and 25 twin pairs concordant for insulin-dependent diabetes. In both groups the mean age at diagnosis was 20 years. Repeat samples were obtained from one concordant and four discordant pairs, and sera from two non-diabetic sibs of the concordant pair were also tested. Samples from 11 noninsulin-dependent twin pairs with maturity onset diabetes all of whom were concordant were also examined. Their mean age at diagnosis was 60 years.

Clinical details appear in table I. The non-diabetic twins in the discordant pairs were studied for up to nine years and all have had at least one (and in most cases several) oral glucose tolerance test, the results of which have all been within the normal range.

TABLE I-Clinical features of twins at time of testing

\begin{tabular}{|c|c|c|c|c|}
\hline Pair types & Co-twins & $\begin{array}{c}\text { Mean } \\
\text { age } \\
\text { (and) } \\
\text { range) } \\
\text { (years) }\end{array}$ & $\begin{array}{c}\text { Mean } \\
\text { duration of } \\
\text { diabetes } \\
\text { (and } \\
\text { range) } \\
\text { (years) }\end{array}$ & $\begin{array}{c}\text { No of pairs } \\
\text { with } \\
\text { history } \\
\text { of diabetes } \\
\text { in 1st degree } \\
\text { relative }\end{array}$ \\
\hline $\begin{array}{l}\text { Discordant insulin- } \\
\text { dependent } \\
\text { (29 pairs: } 11 \mathrm{M}, 18 \mathrm{~F} \text { ) }\end{array}$ & $\begin{array}{l}\text { Diabetic } \\
\text { Non-diabetic }\end{array}$ & $\begin{array}{c}29 \\
(7-62) \\
29 \\
(7-62)\end{array}$ & $\begin{array}{cc}9 \cdot 4 \\
(1 \text { month-29) }\end{array}$ & 3 \\
\hline $\begin{array}{l}\text { Concordant insulin- } \\
\text { dependent } \\
\text { ( } 25 \text { pairs: } 11 \mathrm{M}, 14 \mathrm{~F})\end{array}$ & $\begin{array}{l}\text { 1st diagnosed } \\
\text { 2nd diagnosed }\end{array}$ & $\begin{array}{c}34 \\
(10-66) \\
34\end{array}$ & $\begin{array}{l}15 \cdot 7 \\
(1-44) \\
12 \cdot 2\end{array}$ & 6 \\
\hline $\begin{array}{l}\text { Concordant non-insulin- } \\
\text { dependent } \\
\text { (11 pairs: } 6 \mathrm{M}, 5 \mathrm{~F} \text { ) }\end{array}$ & $\begin{array}{l}\text { 1st diagnosed } \\
\text { 2nd diagnosed }\end{array}$ & $\begin{array}{c}67 \\
(57-81) \\
67 \\
(57-81)\end{array}$ & $\begin{array}{c}8 \cdot 6 \\
(3 \text { months-22) } \\
6 \cdot 7 \\
(0-23)\end{array}$ & \} \\
\hline
\end{tabular}

